\title{
Danske billeder af Rusland i 2010'erne
}

\author{
Flemming Splidsboel Hansen
}

Seniorforsker, Dansk Institut for Internationale Studier (DIIS)

\begin{abstract}
Danish images of Russia in the 2010s
This article surveys how the editorial columns of five leading Danish newspapers treat Russia in the 2010s, building on an earlier study which focused on the first decade of the 2000s (Hansen 2010). The present study finds that the overall negative trajectory associated with Russia has continued, even grown more pronounced. In response, a minority position has developed on the fringes of political life in Denmark, holding that Russia is being demonized and that media coverage is too negative and essentially one-sided. The Danish newspapers surveyed focus on what is seen as an increasingly aggressive Russia violating borders and other established norms, and threatening its neighbours. The editorials reflect the gradual paradigm shift in views of Russia. They now speak openly of the need for Denmark to protect itself and its allies militarily against possible Russian aggression and to prevent Russia from wielding more power through its energy supplies to Europe, including supplies that traverse Danish territorial waters. Other topics in focus include Russia's invasion and subsequent annexation of Crimea, its involvement in the war in Eastern Ukraine as well as its military campaign in Syria.
\end{abstract}

Keywords: editorials, Denmark, Russia, authoritarianism, Ukraine, Syria, human rights

I 2010 skrev jeg i Nordisk Østforum om "danske billeder af Rusland i 2000'erne" (Hansen 2010). Via en gennemgang af lederartikler i de da fem største danske aviser målt efter oplagstal tog jeg temperaturen på det danske samfunds opfattelse af Rusland i dette vigtige tiår. Det var et formativt tiår, hvor Rusland var i rivende transition - politisk, økonomisk og i forhold til opbygningen af en ruslandsk nation.

Lederartiklerne beskrev samlet et Rusland, som i 2000'erne gik fra "halvskidt til værre", og en udvikling, som gjorde landet "stadig mere undertrykkende, utroværdigt og aggressivt" (Hansen 2010: 181). Der var få lyspunkter. Et af de positive aspekter, ifølge kommentarer i de danske aviser, var daværende præsident Dmitrij Medvedev, som dog også fik kritik på grund af sin støtte til Ruslands krig mod Georgien i 2008, og som blev opfattet som forholdsvis svag. Et andet positivt aspekt var Ruslands økonomiske afhængighed af Vesten, som kommentatorer tænkte kunne tøjle nogle af de mere negative tendenser $\mathrm{i}$ russisk politik og på længere sigt bringe den russiske befolkning tættere på vestlige standarder (Hansen 2010: 181).

\footnotetext{
^Kontaktinformasjon: Flemming Splidsboel Hansen, epost: fsha@diis.dk 


\section{FLEMMING SPLIDSBOEL HANSEN}

Sammenholdt med de senere lederartikler må det nok konstateres, at disse forhåbninger ikke blev indfriet. Medvedev viste sig blot at være en parentes i præsidentkontoret, da han i 2012 valgte at trække sig og blive premierminister igen (Black 2015). Den økonomiske afhængighed af Vesten (EU-Kommissionen 2018: 8) bremsede heller ikke Rusland, da landet i 2014 annekterede Krim og engagerede sig militært i krigen i Østukraine og efterfølgende blev pålagt et omfattende sæt af sanktioner af et stort antal vestlige stater (Det europæiske Råd (u.d.)).

2010 virker i dag som en forholdsvis fjern fortid, hvor forholdet mellem Rusland og Vesten var mindre kompliceret end nu. Opsummeringen af de danske lederartikler i årene 2010-2018 må være, at det er gået fra "værre til endnu værre«. De danske aviser fælder en hård dom over det russiske styre. Under præsident Vladimir Putin (2012-) er Rusland internt blevet mere autokratisk, undertrykkende og korrupt, mens det eksternt er blevet mere selvhævdende, aggressivt og normbrydende. De dårlige mediesager spænder fra annekteringen af Krim (2014) og Ruslands militære engagementer i Østukraine (2014-) og Syrien (2015-) over nedskydningen af det malaysiske fly MH17 (2014), drabet på den russiske oppositionspolitiker Boris Nemtsov (2015) og drabsforsøget på den russiske eksspion Sergej Skripal og hans datter Julia (2018) til for eksempel cyberangreb, indblanding i udenlandske valg, desinformation, omfattende valgsvindel, undertrykkelse af seksuelle mindretal, forfølgelse af punkbandet Pussy Riot (2012) og statsstøttet doping af russiske atleter. Listen over dårlige mediesager er ganske lang, og de fleste emner kan genfindes i de største aviser.

Nedenfor præsentererjeg netop udviklingen i de danskelederartikler om Rusland i årene 2000-2018. Jeg har fastholdt fokus på de fem aviser fra den oprindelige artikel (Hansen 2010) for bedre at kunne sammenligne på tværs af de to perioder. De danske aviser er i stigende grad gået væk fra oplagstal, bl.a. fordi den nedadgående tendens påvirker reklameindtægterne negativt, og den foretrukne målestok er nu læsertal. Målt på daglige læsertal er rækkefølgen således: Politiken (237.000), Jyllands-Posten (171.000), Berlingske (145.000), Ekstrabladet (96.000) og BT (81.000). ${ }^{1}$ De tre førstnævnte er alle omnibusaviser, men de to sidstnævnte er tabloidaviser. Lederartiklerne er fundet via en søgning i Infomedia, som overvåger de danske medier. ${ }^{2}$ Jeg har på den baggrund identificeret 311 relevante ledere. Der var flest ledere i Jyllands-Posten, og hvis disse sættes til værdien 100, følger

\footnotetext{
${ }^{1}$ Såvel betalingsaviserne Weekendavisen (197.000), Børsen (115.000) og Kristeligt Dagblad (94.000) som gratisavisen BT Metro (425.000) har tilstrækkeligt store læsertal til at komme på denne liste over de mest læste aviser i Danmark. BT Metro er fravalgt, da den fortrinsvis fokuserer på nære, nationale historier og ikke på samme måde som de traditionelle aviser gør brug af redaktionelle kommentarer. Weekendavisen, Børsen og Kristeligt Dagblad er fraværende, fordi de ikke var inkluderet i den første analyse af lederartikler (Hansen 2010). Læsertallene (1. halvår 2018) er tilgængelige hos Kantar Gallup (2018).

${ }^{2}$ www.infomedia.dk.
} 
derefter Berlingske (88), Politiken (84), BT (17) og Ekstrabladet (14). Det regnes ofte for et definerende træk ved tabloidaviserne, at de i mindre grad end omnibusaviserne har fokus på det udenlandske nyhedsstof (Uribe \& Gunter 2004), og det er derfor forventeligt, at de også i mindre grad behandler udlandsstof på lederplads.

Tidligere undersøgelser af sammenhængen mellem avislæsning og politiske præferencer viser, at Politiken især læses af vælgere, som stemmer på Socialdemokratiet (31\% af alle læsere), SF (23\%), Det radikale Venstre (13\%) og Enhedslisten (12\%). Jyllands-Postens læsere stemmer især på Venstre (30\%), Socialdemokratiet (20\%), Dansk Folkeparti (16\%) og Liberal Alliance (12\%). Berlingskes læsere foretrækker at sætte kryds ved Venstre (28 \%), Liberal Alliance (16\%), Socialdemokratiet (15\%) og De Konservative (11\%). For de to tabloidaviser gælder, at Ekstrabladet især finder sine læsere blandt støtter af Socialdemokratiet, Dansk Folkeparti og Venstre, mens BT især er populær blandt Dansk Folkeparti og Venstres vælgere (Berlingske, den 30. maj 2011).

Jeg har identificeret lidt flere ledere i perioden 2010-2018 (311) end i perioden 2000-2009 (ca. 300), hvilket også indikerer et øget fokus på Rusland. Fordelingen af ledere i omnibusaviser og tabloidaviser er stort set ens i begge perioder. Figur 1 viser fordelingen henover tidsperioden.

Søgningen i Infomedia har været på lederartikler og med søgeordet »Rusland«. Jeg har ikke benyttet yderligere søgeord for at indsnævre søgningen. Denne brede

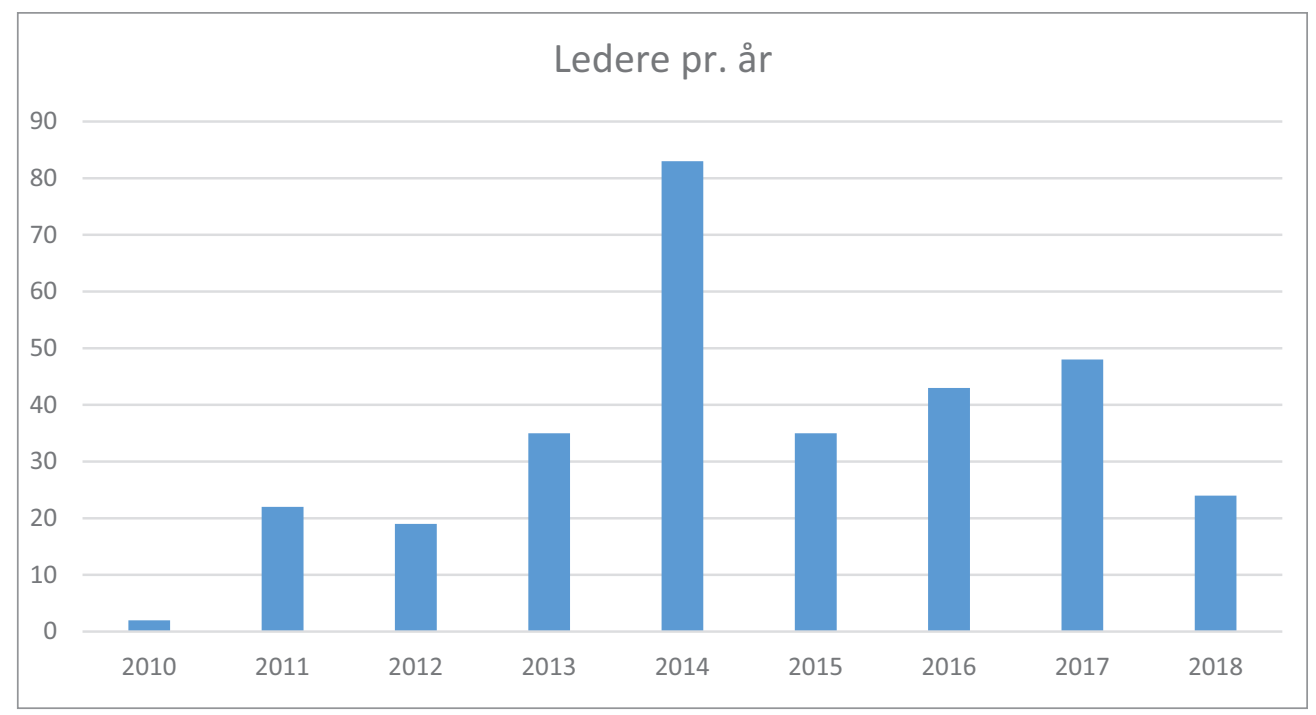

Figur 1. Antal identificerede ledere pr. år (2010-2018)^

* Optellingen af ledere i 2018 sluttede den 11. maj 2018. 
søgning har resulteret $i$ et antal lederartikler, hvor Rusland optræder helt perifert, og hvor omtalen af Rusland ikke er knyttet til en vurdering af udviklingen eller tilstanden i landet. Disse lederartikler er fravalgt, og de er derfor ikke med i opgørelsen i figur $1 .^{3}$

Eftersom formålet med artiklen er at afdække de danske avisers opfattelse af Rusland generelt, valgte jeg ikke at fokusere på særlige temaer i søgningen. Disse temaer - for eksempel krigen i Ukraine eller den politiske udvikling i Rusland fremkom efterfølgende, da de tydeligt dominerede lederspalterne. Mere snævre "single case" studier af mediernes holdning til et specifikt politisk emne som for eksempel militær intervention eller indførelse af sanktioner (Billeaudeaux, Domke, Hutcheson \& Garland 2003, Ryan 2004, Izadi \& Saghaye-Biria 2007) præsenterer ofte kvantificerede oversigter over de enkelte lederes overordnede holdning til det berørte emne (fx positiv-neutral-negativ) eller anvendelse af grundlæggende formodninger eller diskursive greb (fx Ryan 2004:368-372). Denne metode fravalgte jeg til fordel for studier af et større antal temaer.

Lederne er som nævnt fra fem danske aviser. Spørgsmålet er, om en søgning i andre af de større danske aviser ville have givet et andet billede af Rusland? Svaret er overordnet nej - og så må der tilføjes et lille ja. Eksempelvis viser et kig på Information, som læses af en forholdsvis stor andel af Enhedslistens vælgere (Berlingske, den 30. maj 2011), på den ene side en opfattelse af Rusland, som stemmer ganske godt overens med de dominerende opfattelser i de fem behandlede aviser. ${ }^{4}$ Således skrev Information efter Ruslands annektering af Krim, at "lektien er klar: stol aldrig igen på Putin" (den 21. marts 2014), og den spurgte i forbindelse med mistanken om statsstøttet doping af atleter i Rusland, om "Rusland [er] et land med forbrydere? Eller er Rusland forbrydere med et land?« (den 20. juli 2016).

På den anden side noterede Information dog også om Ruslands besættelse af Krim, at "det vil som udgangspunkt ikke skade, hvis EU anerkender Ruslands interesser på Krim i lyset af landenes sammenflettede historie og de mange etniske russere i landet", inden den opfordrede EU til at "anerkende sin egen rolle i krisen" (den 8. marts 2014). Og senere, i forbindelse med en ændring af loven om vold i hjemmet i Rusland, mindede avisen om, at uanset den uheldige udvikling i landet så er det "altså stadig forbudt at slå sin kone og sine børn i Rusland", hvorefter den manede til besindighed med ordene "vi skal huske at balancere billedet - også når det handler om Rusland" (den 27. januar 2017).

\footnotetext{
${ }^{3}$ Fx havde BT (den 10. november 2014) en leder, som markerede og reflekterede over 25-året for Berlinmurens fald. Lederen citerede kort den tidligere sovjetiske leder Mikhail Gorbatjovs advarsel om en mulig ny kold krig, og så noterede den nøgternt, at "uomtvisteligt er det, at vi oplever spændinger mellem Vesten og Rusland, udløst af konflikten i Ukraine«.

${ }^{4}$ Læsertallet for Information er 78.000 (Kantar Gallup 2018).
} 


\title{
Metadebat
}

Udviklingen i kritikken af Rusland i de danske lederartikler i årene 2010-2018 anes måske bedst af det forhold, at der parallelt med debatten om Rusland har udviklet sig en debat $o m$ debatten. For eksempel hævder en rapport fra Danmarks Medie- og Journalisthøjskole, at mediestoffet om Rusland er "stereotypt i den forstand, at det fremstiller Rusland og præsident Putins handlinger på baggrund af en neosovjetisk synsvinkel uden blik for, hvad der kendetegner det nye Rusland ", ligesom det er "vinklet ud fra vestlige værdinormer" (Kabel 2016: 9). Denne rapport er siden blevet den primære reference for de aktører i Danmark, som kritiserer debatten om Rusland. ${ }^{5}$

Den mest fremtrædende af disse aktører er Marie Krarup, medlem af Folketinget for Dansk Folkeparti og indtil september 2018 sit partis forsvarsordfører, som ofte kritiserer de danske mediers dækning af Rusland (Hansen 2018). Krarup bad sågar sine følgere på Facebook om at rangordne de primære danske aviser efter deres kommentarer, især på lederpladsen, om Rusland. Svarene fik hende til at sammenfatte følgende liste (de tre nævnte aviser er alle repræsenteret i denne undersøgelse):

I bund: Berlingske. Glødende antirussisk. Omfattende dækning. Næstdårligst: Jyllandsposten. Standard antirussisk. Ikke så omfattende dækning. Politiken: Meget svingende. Kan både være afbalanceret og det modsatte. Ret omfattende dækning (Krarup 2018).

I forlængelse af dette fremførte Flemming Rose, tidligere udlands- og kulturredaktør på Jyllands-Posten og korrespondent i Moskva for såvel Jyllands-Posten som Berlingske, det synspunkt, at

\begin{abstract}
Hvis man abonnerer på en bestemt ideologi og deler verden op i stammer, hvor nogle er venner, og andre er fjender, vil man være tilbøjelig til at lægge mærke til alt det hos ens egen stamme og hos fjenden, der bekræfter ens verdensbillede, mens alt det, der peger $i$ andre retninger, vil blive filtreret fra. Det er i ekstrem grad tilfældet med Rusland (Rose 2018).
\end{abstract}

Han tilføjede derefter, at "vi foretrækker at se Rusland som tilbagestående, brutalt og ineffektivt, for sådan skal et antivestligt og autoritært regime se ud for at stemme med vores forståelse af verden" (Rose 2018).

Rose peger her på kognitive begrænsninger, som er almindeligt anerkendte ( $\mathrm{fx}$ Heuer 1999), og som også fremføres fra russisk side som kritik af kritikken af Rusland (Hansen 2010).

Fra den anden side af debatten forklarede en daværende udlandsredaktør på Berlingske, at "det er korrekt, at dækningen af Rusland er meget kritisk. Men det skyldes simpelthen virkeligheden. Det skyldes, at der er meget at være kritisk over.

\footnotetext{
${ }_{5}^{5}$ Fx Marie Krarup på Facebook (den 20. februar 2018). Min egen forskning bliver også kritiseret for at være tendentiøs og unuanceret (Kabel 2016: 18). Kabel erkendte dog senere, at han intet har læst af min forskning (personlig kommunikation, den 18. september 2017).
} 
Og det er mediernes opgave at viderebringe, hvad der sker". Hun tilføjede, at »jeg mener ikke, at vi dæmoniserer. Det, vi skriver, er det, der foregår i Rusland. Rusland og Putin vil bruge alle midler for at få mere magt. Det er et erklæret mål. Det kan man mene, er negativt eller positivt, men det er sådan, det er" (citeret i Barlag 2016).

En journalist (Bennetts 2018) opsummerede dilemmaet i The Moscow Times, da han skrev, at

It is true, of course, that - for most people anyway - life in Russia is not one unrelenting cycle of doom and misery. But it is the very nature of news reporting to dwell on tensions, disputes, abuses and allegations. And Russia provides plenty of opportunities for such reporting, from the high-level corruption that even the Kremlin has admitted is a major problem to accusations of torture by police and other security services, not to mention a growing crackdown on dissent.

Studier viser, at negative nyheder ("bad news") dominerer nyhedsbilledet (Harcup \& O’Neill 2017; Haagerup 2015). Det negative aspekt må formodes at være endnu mere dominerende i lederspalterne, da lederne typisk har som mål at være handlingsanvisende (Izadi \& Saghaye-Biria 2007). På baggrund af en identificeret problemstilling, ofte informeret af et særligt ideologisk ståsted (van Dijk 1998), forklarer lederen, hvad der bør gøres. Dette kan for eksempel være at anbefale at indføre sanktioner eller at indkøbe nye våbensystemer, eller det kan være at anbefale øget samarbejde for at mindske et konfliktfyldt forhold. Lederen er heller ikke på samme måde som den øvrige journalistik bundet af hensyn til objektivitet (Ryan 2004: 365) - det er en opinionsgenre, og den indeholder derfor først og fremmest holdninger (Nordenson 2008). Jyllands-Posten forklarer dette eksplicit på lederplads, hvor redaktionen forklarer, at "Dette er en leder: Jyllands-Posten er en liberal avis, hvilket kommer til udtryk på lederplads - mens journalistikken lever sit eget, frie og uafhængige liv. Vi skelner skarpt mellem journalistik og meningsstof " ${ }^{6} \mathrm{Vi}$ finder her både ideologien og de mere frie rammer i opinionsgenren.

De nævnte eksempler falder lige ned i debatten om journalistisk objektivitet og om mediernes evne til at bringe forbrugerne - borgerne - tættere på en observatørneutral forståelse af det behandlede emne, i dette tilfælde Rusland ( $\mathrm{fx}$ Muñoz-Torres 2012 \& Ryan 2004). Kritisk, postpositivistisk medieteori afviser dette og insisterer i stedet på, at »ingen journalist kan vide uden at lave vurderinger, og disse forudsætter nødvendigvis et tidligere sæt af koncepter og værdier" (fx Muñoz-Torres 2012: 575). Denne afvisning åbner dog ikke døren for en fuldstændig relativisering med frit valg på alle forståelseshylder, og hvor alt har lige sandhedsværdi (Muñoz-Torres 2012: 576).

Det ser vi til gengæld i dele af den statskontrollerede russiske mediestrategi, således som den er udformet af præsident Vladimir Putins rådgiver Vladislav Surkov. Strategien afspejler debatten om objektivitet og tager den til sit postpositivistiske

\footnotetext{
${ }^{6}$ Se www.jyllands-posten.dk/debat/leder.
} 
ekstreme: Udgangspunktet er, at "alle nyheder er konstruerede", og at alle konstruktioner hviler på paradigmer, som informerer analysen. Sat helt på spidsen hævdes det i denne mediestrategi, at intet kan siges at have større sandhedsværdi end andet (Pomerantsev 2017; Hansen 2017). Strategien kommer til udtryk i en ekstrem perspektivisme, hvor ofte mange og meget forskellige fortolkninger af nyheder præsenteres på et (internationalt) nyhedsmarked. Der kan forbrugeren så vælge mellem tilbuddene (Hansen 2017). Denne ekstreme perspektivisme, især som den udtrykkes fra russisk side, har ganske bemærkelsesværdigt ført til en fornyet diskussion om journalistisk objektivitet, og tendensen synes at være en tilbagevenden til en insisteren på objektivitet, $\mathrm{i}$ det mindste $\mathrm{i}$ journalistisk metode (fx Collignon 2018).

På denne måde har Rusland - som emne og som aktør - givet anledning til to væsentlige mediedebatter i Danmark. Den mest umiddelbare knytter sig til karakteren af de danske mediers dækning af Rusland - »hvor virkelighedstro er denne dækning?«. Den anden knytter sig til den ekstreme perspektivisme, som ligger til grund for dele af den statskontrollerede russiske mediestrategi, og som har tvunget redaktører, journalister og nyhedsforbrugere til at forholde sig til vanskelige begreber som objektivitet og sandhed (fx Muñoz-Torres 2012). Dette er en ny udvikling i forhold til 2000'erne, hvor den første debat blot kunne anes svagt, mens den anden slet ikke var til stede.

\section{Missiler og naturgas}

I januar 2018 fik Danmark en ny forsvarsaftale for årene 2018-2023 (Forsvarsministeriet 2018). Et bredt flertal i Folketinget stod bag aftalen, som skulle give det danske forsvar "et substantielt løft", herunder en forbedret evne til at bidrage til "NATO's kollektive afskrækkelse og forsvar» (Forsvarsministeriet 2018: 1). En væsentlig del af bagtæppet for aftalen var, med aftalens egne ord, "et udfordrende og mere selvhævdende Rusland« (Forsvarsministeriet 2018: 2).

Aftalen kan ses som det hidtil klareste tegn på et paradigmeskifte i opfattelsen af Rusland i Danmark, blandt andet på grund af indkøbet af nye våbensystemer (fx missiler til luftforsvar og slæbesonarer til ubådsbekæmpelse) og oprettelsen af en ny og deployerbar brigade. De danske aviser støttede generelt såvel fortolkningen af Rusland som de forsvarspolitiske tiltag. Forsvarsdebatten ændrede karakter allerede ved Ruslands invasion af Krim i februar 2014, dvs. blot et år inde i det tidligere fireårige forlig (2013-2017).

Få uger efter invasionen af Krim slog Berlingske for eksempel fast, at Rusland havde anvendt "rå magt til at ændre på Europas grænser», og at virkeligheden i Danmark var, at "dansk forsvar er (...) ikke i stand til at forsvare dansk territorium" (Berlingske, den 14. marts 2014). Det blev fulgt op med en advarsel om, at »der er brug for at kunne sende militære styrker til de baltiske lande og Østeuropa med kort varsel til at imødegå russisk pres" (Berlingske, den 20. marts 2014). På den måde anslog Berlingske allerede i marts 2014 det overordnede tema for det senere 
forlig - frygten for Rusland og Danmarks evne til at beskytte sig selv og allierede mod russisk aggression.

Politiken udtrykte mere snævert støtte til den allerede eksisterende aftale om et dansk bidrag (F16-fly) til afvisningsberedskabet for Estland, Letland og Litauen, som blev oprettet i 2004, og som Danmark havde støttet ved tidligere lejligheder. Politiken slog fast, at »F16-flyene er (...) ikke en skærpelse af situationen, men en bekræftelse af den gensidigt anerkendte orden«, og avisen tilføjede, at »hvis de baltiske lande og Polen ikke var medlemmer af NATO [North Atlantic Treaty Organization], havde de al mulig grund til ligesom Ukraine at frygte Putins Rusland " (Politiken, den 28. marts 2014). Ekstrabladet forsøgte på den anden side at tale de danske politikere fra at forny dansk støtte til beredskabet: »Den eneste mulige løsning [for udviklingen i Ukraine] «, forklarede avisen, "må findes ved forhandlingsbordet. Og ikke via militær optrapning (Ekstrabladet, den 19. marts 2014). Fire danske F-16-fly ankom efter en beslutning i Folketinget til Estland i april 2014.

Jyllands-Posten anbefalede øgede forsvarsudgifter, idet Danmark sammen med sine allierede i NATO nu var presset fra flere sider: "For det første i kampen mod Rusland. For det andet fra Mellemøsten, hvor IS [Islamisk Stat] har fået uhyggeligt fodfæste, og for det tredje i det arktiske område, som efter års forsøg på fredelige løsninger igen kan blive varmt, hvis Rusland også dér vælger at gå egne veje frem for at holde sig til de internationale spilleregler" (Fyllands-Posten, den 4. september 2014). Danmarks forsvarsbyrde skulle øges, og Rusland var en årsag til dette, men der var også andre udfordringer, herunder IS, og de måtte ikke glemmes. Uafhængigt af synspunkter som dette opstod faktisk senere, som en del af debatten om debatten, et kortvarigt politisk slagsmål om, hvorvidt Rusland eller IS udgjorde den største trussel mod Danmark, og om hvorvidt der blev manipuleret med offentlighedens opfattelse af Rusland. ${ }^{7}$

Udbruddet af krig i Østukraine (Wood, Pomeranz, Merry \& Trudolyubov 2016 \& Tumakova 2018) i foråret 2014 og et fortsat stigende spændingsniveau i Østersøregionen (Dahl 2018) bragte gradvis alle de danske lederskribenter tættere på en entydig anbefaling: At styrke forsvaret mod den trussel, som Rusland bliver vurderet at udgøre mod danske interesser. Berlingske fortsatte linjen som lagt allerede i foråret 2014, da avisen bl.a. hævdede, at "Danmark sikkerhedspolitisk har fået voldsomt meget mere brug for NATO end de fleste øvrige NATO-medlemmer som følge af Ruslands nyimperiale adfærd overfor de tidligere Sovjetrepublikker", og forklaringen var, at "i tilfælde af en konflikt mellem Rusland og de baltiske lande kan Danmark dårligt undgå at blive inddraget" (Berlingske, den 11. august 2015). Da konturerne af det nye forlig blev mere tydelige, støttede Berlingske (den 7. juni 2017)

\footnotetext{
${ }^{7}$ Marie Krarup hævdede i januar 2017, at den årlige Efterretningsmessig Risikovurdering fra Forsvarets Efterretningstjeneste (2017: 9) begik en "fantastisk afledningsmanøvre», da den beskrev truslerne fra først Rusland og dernæst IS; i Jyllands-Posten (den 23. januar 2017).
} 
oplægget om et forsvar mod russiske missiler og en styrket kapacitet til at bistå Estland, Letland og Litauen i tilfælde af et russisk angreb på disse stater.

Jyllands-Posten (den 17. august 2015) slog fast, at "med Ruslands annektering af Krim og med Ruslands ageren i Ukraine står det klart, at truslen fra øst ikke længere kan negligeres". Anbefalingen var på denne baggrund at indkøbe F-35-fly til erstatning for F-16-flyene, for "med den geopolitiske udvikling i Rusland in mente vil Danmark reelt være forsvarsløst uden et flyvevåben med kampfly til på samme tid at håndhæve dansk suverænitet og være aktiv i internationale operationer" (FyllandsPosten, den 27. august 2015). ${ }^{8}$ Avisen (Fyllands-Posten, den 28. oktober 2016) opsummerede senere med den sikkerhedspolitiske diagnose, at

Præsident Putin puster sig op til den ene manddomsprøve efter den anden. Han lader bombefly ødelægge resterne af Syrien. Han sender krigsskibe med langtrækkende missiler gennem Storebælt. Han opstiller andre missiler - der kan medføre atomvåben, som kan ramme mål i Tyskland og Danmark - i Kaliningrad. Russiske kampfly har tidligere simuleret angreb mod Bornholm. For godt to år siden annekteredes Krim, og i Baltikum er man, forståeligt nok, urolig for, hvad Putin ellers kan finde på.

BT (den 15. november 2016) advarede om, at "i dag aner vi ikke, hvad galningen Putin kan finde påı, og Danmark måtte derfor "opruste med både mandskab og materiel i en genopbygning af territorialforsvaret for Østersøen og for Arktis«. Politiken (den 13. oktober 2017) var enig, og i en afvisning af russisk kritik af de danske forsvarsforhandlinger mindede avisen om, at Rusland er årsag til, "at europæerne igen føler sig presset til at poste flere penge i deres forsvar». Problemet er, ifølge Politiken, at "vi ikke længere kan regne med, at Rusland respekterer Europas grænser", og at Rusland har "bidraget til en følelse af utryghed ", "igen og igen er sat i forbindelse med cyberangreb på vestlige lande og demokratier" og "har sået tvivl om sine fredelige hensigter (...) i grænselandet til både Østersøen, EU [Den Europæiske Union] og NATO«.

Politiken advarede dog også om, at politikerne overdrev truslen fra Rusland, og at den danske oprustning kunne føre til øget spænding i Østersøområdet især. For eksempel skrev avisen forud for de sidste forhandlinger om forliget, at "forsvarsministeren har effektivt malet det store krigs- og frygtscenarie", inden den tilføjede, "men hånden på hjertet: Intet tyder på, at Vladimir Putin er på vej mod Køge Bugt" (Politiken, den 12. november 2017). Da forliget var lukket og indholdet meddelt til offentligheden, begræd Politiken (den 29. januar 2018), at forliget »introducerer de frygtede Tomahawkkrydsermissiler på danske fregatter i Østersøen, der vil blive opfattet som en militaristisk og fjendtlig handling i Moskva«..$^{9}$ De fleste lederskribenter

\footnotetext{
${ }^{8}$ Et flertal i Folketinget besluttede i juni 2016 at indkøbe 27 F-35-fly (femte generation) til erstatning for flåden af F-16-fly (fjerde generation).

${ }^{9}$ Partierne bag forsvarsforliget besluttede at undersøge »behovet for at anskaffe længererækkende præcisionsmissiler (strike-kapacitet) (...) gennem et indledende analysearbejde med henblik på vurdering af en eventuel efterfølgende anskaffelse på mellemlangt sigt (2023-2026)« (Forsvarsministeriet 2018: 5). Der er i forliget lagt op til, at det danske forsvar skal kunne nedskyde missiler affyret fra baser i fx Kaliningrad, men en anskaffelse af en "strike-kapacitet« ville i givet fald betyde,
} 
var enige om at lægge skylden for den øgede spænding hos det russiske styre, men der var således også enkelte stemmer, som advarede om, at Danmark og dets allierede utilsigtet selv bidrog til denne udvikling.

Et andet emne med stærke sikkerhedspolitiske aspekter var naturgasrørledningen Nord Stream 2 (Goldthau 2016). Projektet har haft særlig betydning for Danmark, idet rørledningen, som den allerede etablerede Nord Stream 1, er planlagt til at krydse dansk søterritorium ved Bornholm. Nord Stream 2 har været en vanskelig sag at håndtere for Danmark, især på grund af et stærkt krydspres med Rusland (det statsejede naturgasselskab Gazprom ejer konsortiet bag Nord Stream 2) og Tyskland (hovedaftager af naturgassen) på den ene side og en lang række kritiske lande, anført af USA, på den anden side (fx Osmolovska 2018).

Berlingske (den 18. december 2015) ridsede udfordringen op, da avisen forklarede sine læsere, at "alt $i$ alt vil den danske regering stå sig ved at indrømme, at der er tale om sikkerhedspolitik", inden den tilføjede, at Danmark burde afstemme sin position med andre aktører, herunder Finland og Sverige, da "det vil gøre det lettere at påkalde sig andre landes hiælp, hvis vi en dag skal træffe en beslutning, der går Rusland imod". I december 2017 vedtog Folketinget faktisk en ny "Lov om ændring af lov om kontinentalsoklen", hvorefter Danmark alene vil tillade nedlæggelsen af rørledninger til transport af kulbrinter, "hvis det er foreneligt med rigets udenrigs-, sikkerheds- og forsvarspolitiske interesser" (Retsinformation 2017: $₫ 1$, stk. 2). Der vil således blive foretaget en helhedsvurdering, og ganske kontroversielt er der ingen ankemulighed efter et muligt afslag (Retsinformation 2017: \$1, stk. 13). Nord Stream 2 er ikke nævnt i loven, men der er ingen tvivl om, at netop dette projekt var baggrunden for den nye lov. Med dette drastiske skridt banede Folketinget vej for at afvise ansøgningen fra Nord Stream 2. ${ }^{10}$

De danske lederskribenter var stort set alle enige om, at ansøgningen om at lade Nord Stream 2 krydse dansk søterritorium skulle afvises. Der var flere argumenter. Helt overordnet var det opfattelsen, at Ruslands ageren på andre politikområder og i andre arenaer $i k k e$ kunne skilles fra spørgsmålet om leverancer af naturgas til de tyske husholdninger. For eksempel argumenterede BT på et tidligt tidspunkt for, at wi lyset af de russiske [militære] provokationer i vores nærområde og krigsforbrydelserne i Aleppo [i Syrien] kan Danmark principielt ikke belønne Putin med adgang til vores farvande. Vi må kappe gasforbindelsen til Putin«. Rent energipolitisk, tilføjede avisen, var projektet dog også problematisk, da det "vil give Rusland en alt for stor indflydelse på Europas energiforsyning" (BT, den 27. oktober 2016).

Jyllands-Posten (den 10. april 2017) fortsatte ad det storpolitiske spor, da avisen noterede, at »i en situation, hvor forholdet til Rusland er det dårligste siden Den

at det danske forsvar ville kunne destruere de russiske missiler inden affyringen og altså på jorden i fx Kaliningrad.

${ }^{10}$ I skrivende stund - juni 2018 - har Danmark endnu ikke truffet en beslutning om Nord Stream 2. 
Kolde Krig, og hvor der er indført økonomiske sanktioner som følge af Ruslands annektering af Krim og den paramilitære fremfærd i Ukraine, tilsiger absolut intet, at den danske stat skal tillade etableringen af Nord Stream 2«. Berlingske gjorde det kort klart, at det i lyset af Ruslands udenrigspolitik ville være "absurd" at "godkende et stort infrastrukturprojekt, som Rusland kan bruge til yderligere at presse sine nabolande (den 28. marts 2017). Efter giftangrebet på Skripal og hans datter Julia i England i marts 2018 anbefalede Jyllands-Posten under overskriften »Koldkrig 2.0« (den 15. marts 2018), at hvis "EU kunne tage sig sammen" til at koble Nord Stream 2 til sanktionsregimet mod Rusland efter giftangrebet, »burde Danmark erklære sig enig«. Det ville, fortsatte Jyllands-Posten (den 23. marts 2018), »klæde Danmark også her at vise Rusland, hvor grænsen går».

\section{Det autoritære og illiberale Rusland}

Men hvilket Rusland er det da, de ser, de danske lederskribenter, som støtter et forsvarsforlig med væsentligt større fokus på Rusland og anbefaler, at Danmark ser rørledninger som storpolitik? Præsidentvalget i Rusland i marts 2018 gav skribenterne en oplagt anledning til at gøre det politiske bo op, og kritikken var hård. Under overskriften "Putin kåret" konkluderede Ekstrabladet (den 20. marts 2018), at "de andre præsidentkandidater havde ikke en chance. De store russiske medier, der alle er statskontrollerede, støttede Putin døgnet rundt i valgkampen, mens hans rivaler nærmest blev tiet ihjel. Eller gjort til grin. Eller fængslet«. Jyllands-Posten (den 19. marts 2018) havde en lignende fortolkning, idet avisen beskrev, hvorledes "resultatet var klart på forhånd, der blev snydt og bedraget, og enhver oppositionspolitiker, som måske kunne have udfordret ham, var på forhånd blevet udelukket«.

I et lidt bredere politisk perspektiv forklarede Politiken (den 20. marts 2018) bl.a. sine læsere, at »russerne er blevet udsat for en systematisk statslig manipulation, der har skullet overbevise dem om, at Vladimir Putin er deres bedste værn mod et fjendtligt Vesten«, og at "russisk stats-tv og russiske politikere [har] tegnet et billede af Rusland som offer for vestlige sanktioner og "antirussiske handlinger". Politiken advarede om, at Putin har udviklet sig til en leder, "hvis styreform vi andre aldrig må acceptere som hverken normal eller legitim» (Politiken, den 20. marts 2018). Berlingske (den 20. marts 2018) så en mere grundlæggende udvikling i Rusland og konkluderede, at "selv om tanken om et Rusland uden Putin ved roret kan virke forjættende, er landets udvikling væk fra demokratiske forestillinger snart nået så vidt, at Putin er irrelevant i det store billede». Sagen er, hævdede avisen, at Putin siden 1999 har haft held til at skabe "en alternativ fortælling, der vender mange russere bort fra forestillingen om det liberale demokrati som den mest nødvendige styreform «. ${ }^{11}$ Jyllands-Posten (den 19. marts 2018) gjorde det da også klart for sine

\footnotetext{
${ }^{11}$ Jeg har selv beskrevet denne udvikling i Hansen 2016.
} 
læsere, at »Putin formodentlig ville have vundet, selv om det hele var foregået frit og demokratisk".

De danske aviser ser - ikke overraskende - et russisk styre, som har udviklet sig i en udemokratisk og illiberal retning. Denne tendens blev påpeget af de danske lederskribenter allerede i 2000'erne (Hansen 2010: 172-174), men den bliver nu vurderet til at være blevet endnu stærkere. Politiken (den 20. september 2016) beskrev det i dramatiske vendinger, da avisen efter Duma-valget i september 2016 noterede, at "Vladimir Putins kvælertag på det russiske demokrati [er nu] så stramt, at præsidentens modstandere ikke længere kan få luft". Vurderinger fra den amerikanske NGO Freedom House bekræfter billedet af en udemokratisk og illiberal udvikling. I 2018 gav Freedom House således Rusland en score på 7 for dets politiske rettigheder og en score på 6 for dets personlige friheder (på en skala hvor 1 er mest frit og 7 er mindst frit). De tilsvarende scorer var henholdsvis 6 og 5 i 2010 og 5 og 5 i 2000-2001 (Freedom House 2018). I faglitteraturen vurderes det generelt også, at Rusland har taget denne drejning siden 2010 og især efter parlaments- og præsidentvalgene i hhv. 2011 og 2012 (fx Shevtsova 2015; Gelman 2015; Kolesnikov 2017 \& Fish 2017; for yderligere diskussion se fx Inozemtsev 2017 og Gessen 2017 foruden Javelin \& Lindemann-Komarova 2010).

Vurderingen af mobiliseringen af de russiske vælgere, især udbredelsen af den store fortælling om Ruslands rolle i verden og Putins afledte muligheder for at vinde selv uden valgsvindel, berører spørgsmålet om læring (Checkel 2001; Saari 2009; Donno 2013). De netop citerede lederartikler indikerer en (yderligere) tilbagerulning af nogle af de politiske normer, som i det mindste formelt var dominerende $i$ 1990'erne, og hvis skæbne endnu var uafklaret i 2000'erne. Politiken (den 20. marts 2018) har bemærket, at Putin fra starten af sin politiske karriere har haft som mål at rulle det russiske demokrati tilbage. Berlingske (den 17. maj 2015) konstaterede i 2015, med henvisning til den officielle russiske fortolkning af anden verdenskrig og Sovjetunionens rolle i krigen, at "for hver dag der går, fjerner Rusland sig længere og længere fra Europa, og de værdier, Europa bygger på«. Denne opfattelse - at det russiske styre har haft held til at gennemføre en "aflæring" af tidligere normer og en (gen)læring af nye eller måske rettere gamle normer - er udbredt i lederspalterne. Den kommer tydeligt til udtryk i mange af de sager fra Rusland, større såvel som mindre, som tiltrak så megen opmærksomhed, at de blev kommenteret på lederplads. Jeg præsenterer en række af disse sager nedenfor.

Inden skal det dog bemærkes, hvorledes Jyllands-Posten (den 19. marts 2018) ved sin afvisning af præsidentvalget i 2018 også noterede, "at tænke sig, mere end hver femte vælger stemte ikke på [Putin] «. De danske lederskribenter ser et autoritært system ledet af en præsident, som har haft held til at samle en stor del af befolkningen omkring sig i oprigtig støtte. Det har han bl.a. gjort ved at "gøre [Vesten] til fjenden i fortid og nutid" (Berlingske, den 17. maj 2015), med "nationalistisk bragesnak" (Fyllands-Posten, den 19. marts 2018), med "åbenlys propaganda" (Politiken, den 20. september 2016), ved at "investere i militæret som et slags potensmiddel for 
en ellers rusten atommagt" (Fyllands-Posten, den 16. december 2017), ved at være "symbolet på den stærke mand og den stærke centralmagt" (Ekstrabladet, den 20. marts 2018). Men lederskribenterne ser også et system med indbyggede svagheder, og det er disse svagheder, som førte til, at mere end hver femte vælger ikke stemte på Putin i 2018, og som på sigt kan skabe større udfordringer for det russiske styre.

Centralt på listen over svagheder står økonomien. Jyllands-Posten (hhv. den 18. august 2016 og den 16. juni 2016) har for eksempel beskrevet Rusland som "en falleret stat" med »en nærmest afrikansk økonomi« og »med enorme problemer, økonomisk, demografisk, politisk«. Ifølge Politiken (den 21. december 2014) ligger der et grundlæggende problem i, at »korruption, nepotisme og manglende retssikkerhed [fortsat gennemsyrer] hans styre«. Og Berlingske (den 17. maj 2015) noterede, at "vi kan gennem den fælles sanktionspolitik og hjulpet af de lave oliepriser forhindre, at et Rusland, der vender sig mod os, bliver rigt og magtfuldt«. Berlingske så således også i de økonomiske problemer en mulighed for at påvirke Rusland, hvilket er en del af rationalet bag materielle sanktioner (Drezner 2009). Der blev dog også advaret om, at for omfattende problemer i Rusland ikke er til Vestens fordel. For eksempel mindede Politiken (den 21. december 2014) om, at "det har aldrig været hensigten med sanktionerne at skubbe Rusland ud over kanten og slet ikke at straffe det russiske folk for Putins mislykkede og uheldsvangre politik«. Jyllands-Posten (den 18. august 2016) gjorde det tilsvarende klart, at Ruslands grundlæggende problemer ikke skulle give anledning til "glæde eller hovmod", idet avisen tilføjede, at "det bør være i alles interesse, at Ruslands handel, produktion og levestandard kommer op på højde med vestlige og østeuropæiske landes«.

\section{De mange dårlige sager}

Der har været mange dårlige sager for Rusland i årene 2010-2018, og de har fyldt meget i dækningen. Dette billede er en væsentlig del af baggrunden for debatten om debatten, hvor kritikere hævder, at dækningen af Rusland er for ensidigt negativ. Faktisk har der været så mange dårlige sager, at de ikke alle kan gennemgås her. De væsentligste emner blev kort præsenteret $\mathrm{i}$ indledningen.

Såvel Ukraine som Syrien har allerede været berørt i forhold til den helt overordnede politik over for Rusland, det samme har spørgsmålet om, hvorledes Danmark og Vesten bedst håndterer Rusland. Invasionen af Krim i februar 2014 førte til skarp kritik af Rusland i de danske medier. BT (den 6. marts 2014) noterede for eksempel, at Putins forsøg på at legitimere invasionen af Krim var "samme taktik som [Adolf] Hitler benyttede for 76 år siden". Også Berlingske (den 6. marts 2014) fandt, at "det er desværre ikke helt forkert at sammenligne Putins magtspil med truslen om invasion i Ukraine lige i baggrunden med optakten til Anden Verdenskrig, hvor Hitler havde held til at skræmme vestmagterne til at acceptere, at Hitler indlemmede grænseområder til Frankrig og Tjekkoslovakiet med begrundelsen, at 
tyske befolkningsgrupper skulle beskyttes", og Jyllands-Posten (den 8. marts 2014) noterede, at "indmarchen i Sudeterlandet 1938, angiveligt for at redde tyskere iTjekkoslovakiet, virker som en drejebog for begivenhederne på Krim".

Med brugen af denne historiske analogi var det ikke overraskende, at de danske lederskribenter blankt afviste annekteringen, og at der blandt dem også var støtte til at indføre sanktioner mod Rusland. ${ }^{12}$ Den kom stærkest til udtryk i Berlingske, som under overskriften "Vestens reelle magtesløshed" (den 22. marts 2014) konstaterede, at det var vanskeligt for Vesten at påvirke Rusland, men ifølge avisen er "det langsigtede svar (...), at Vesten må samle kræfterne, så vi både besidder den fornødne styrke og vilje til at sikre de frie samfund. Imens kan vi kun fortsætte sanktionsvejen og holde fast i, at de kan udvides". Senere (den 2. august 2014) insisterede Berlingske på, at "Putins nye europæiske krig rokker ved troen på, at Europa kan udvikle sig fredeligt, og Putin må og skal tages alvorligt af Europas ledere, også selvom det kommer til at koste på velfærd og arbejdspladser».

Efter nedskydningen af MH17 den 17. juli 2014 anbefalede Politiken (den 22. juli 2014), at "EU bør skrue op for [sanktionerne] i dag, men aldrig stoppe med at tænke på i morgen«. Denne sidste tilføjelse fra Politiken - en påmindelse om at forholdet til Rusland også skal plejes og bevares - viser kompleksiteten i håndteringen af Rusland. Jyllands-Posten (den 26. marts 2014) advarede om, at NATO skulle holde sig ude af konflikten om Ukraine, og avisen påpegede, at "en bæredygtig løsning for Ukraine kræver i stedet et tæt samarbejde mellem EU og Rusland. Jo længere Bruxelles og Moskva er på kollisionskurs, jo større er risikoen for, at Ukraine falder fra hinanden". Selv hvis der er enighed om brugen af en historisk analogi, kan der være et vist fortolkningsrum, for så vidt angår det passende svar.

Lederskribenterne har udtrykt uenighed om, hvad Rusland egentlig ønsker i Ukraine og i andre tidligere Sovjetrepublikker. Samme uenighed kan naturligvis findes i den videnskabelige litteratur og har sit udgangspunkt i ofte ikke-erklærede og måske endog ikke-erkendte forestillinger om verden generelt og om Rusland og det russiske styre specifikt (fx Sapper \& Weichsel 2015, Liik 2017, Kolesnikov 2017, Ross \& Savchenko 2018 og Ioffe 2018).

I sin argumentation for sanktioner opfordrede Berlingske (den 31. august 2014) til, at vi »i Vesten (...) bør holde op med at stikke os selv blår i øjnene. Det er i høj grad os, der afgør, hvor stor en del af Ukraine, Rusland sætter sig på». Budskabet var klart - udfordringen kræver et håndfast svar fra Vestens side. Og i en kommentar til debatten om debatten, denne gang konkret om Ruslands militære engagement i Østukraine, ironiserede avisen over, at "adskillige såkaldte eksperter [har] advaret mod at tro, at Rusland stod bag. For kan det ikke være, at de russiske oprørere bare på egen hånd er draget dertil? (...) Vi skal passe på med at dæmonisere Rusland, har omkvædet lydt" (den 31. august 2014).

${ }^{12}$ For brugen af historiske analogier se fx Kornprobst (2007). 
Under overskriften »Vesten må forberede sig på flere overraskelser«, spurgte Politiken (den 15. august 2016) »hvad er Ruslands præsident Vladimir Putin ude på?«. Herefter gav avisen selv flere mulige svar i form af "nye erobringer ved Sortehavet? Bare lidt nationalistisk vildskab til ære for de russiske vælgere (...)? Mere pres på den ukrainske regering, som han igen kalder fascistisk?». Problemet er, sagde Politiken, at »Putin er initiativrig og impulsiv«, og den anbefalede på den baggrund, at »Putin skal have hurtige og klare svar».

Jyllands-Posten (den 26. marts 2014) advarede på sin side mod at overvurdere risikoen. Da general Philip Breedlove, daværende Supreme Allied Commander Europe (SACEUR) i NATO, i marts 2014 advarede om, at russiske tropper var på vej til Moldova via Ukraine (Freeman 2014), kommenterede avisen generalens »forvrøvlede udtalelse«. Der er, mindede Jyllands-Posten om, "tale om en tur på $750 \mathrm{~km}$ gennem et område, hvor russerne vil møde voldsom modstand. Desuden har Moskva i forvejen flere end 2.000 soldater i Transnistrien«.

Problemkomplekset »Ukraine« har været svært at håndtere for de danske lederskribenter. Annekteringen af Krim blev afvist, og nedskydningen af MH17 blev fordømt og Rusland udpeget til medskyldig (fx BT, den 21. juli 2014 og Politiken, den 22. juli 2014), men forholdene i Ukraine fortjente også kritik (fx Fyllands-Posten, den 21. november 2014), og det har skabt et billede med forholdsvis mange nuancer. Samtidigt har konflikten og krigen trukket ud, og uden en løsning i sigte har det været vanskeligt at bevare fokus på lederpladserne. Denne tendens blev forstærket af Ruslands militære engagement i Syrien, som påkaldte sig opmærksomhed, og som indirekte skubbede Ukraine i baggrunden. Det ses tydeligt i antallet af lederartikler, som var størst fra 2013 (da primært om interne ukrainske forhold og EU's forhold til landet) og frem til 2015. Derefter er der ganske lille interesse.

Fokus skiftede i stedet til Syrien. Ruslands militære engagement i Syrien fra september 2015 blev mødt med hovedrysten og kritik af de danske lederskribenter. BT (den 2. oktober 2015) benyttede overskriften "Putins brutale logik» til at forberede læserne på, at en "grum magt« muligvis ville dukke frem, "når krudtrøgen letter». BT introducerede samtidig ordet maskirovka, "det russiske låneord for maskeret krigsførelse. Udtænkt som en særlig raffineret disciplin i Sovjettiden for at snyde fjenden i krig. I bund og grund handler det om at sige eller signalere en handling eller politik. Og så gøre det modsatte«. Det var, kunne læseren forstå, et kynisk Rusland med en skjult dagsorden, som havde gjort sin entre på kamppladsen i Syrien. Berlingske (den 4. oktober 2015) var tilsvarende pessimistisk, da avisen konstaterede, at russerne "forstår kun én ting. Magtens sprog", og Politiken (den 5. oktober 2015) så, at Rusland »bevæger sig fra at kunne være en del af løsningen til at blive en del af problemet«. Politiken opsummerede udviklingen ved at slå fast, at Putin har

i fire et halvt år forsynet [præsident Bashar] Assad med våben uanset diktaturets brug af tøndebomber og krigsførelse mod civile. Putin har ikke hjulpet syriske flygtninge med asyl. I stedet hjælper han nu syrernes bøddel under påskud af, at det er den forbryderiske IS-bevægelse, han vil hjælpe med at slå ned på«, og den tilføjede, 
at »Ruslands koldsindige indblanding drejer sig snarere om at beskytte Assad og Ruslands egen interesse i militære baser i det nordvestlige Syrien".

Politiken havde faktisk allerede tidligere kritiseret Ruslands rolle i Syrien. Avisen skrev på et tidligt tidspunkt (den 18. juli 2012) om "russisk kynisme" og senere, i 2013, da Putin appellerede til USA om ikke at intervenere militært i den syriske borgerkrig, konstaterede den, at "det er Putin, der er styrets vigtigste våbenleverandør. Hvis Putin faktisk ønskede det, kunne han tvinge Assad til forhandlingsbordet (...). Fri os for dette let gennemskuelige hykleri, hr. præsident" (den 9. september 2013).

Da russiske styrker blev direkte involveret i kamphandlingerne i september 2015, blev kritikken skarpere. ${ }^{13}$ Jyllands-Posten (den 7. oktober 2016) fremlagde det store historiske perspektiv og noterede, at "russiske soldater har efter Anden Verdenskrig sjældent bidraget til noget positivt (...). Nu har man så kastet sig over resterne af Syrien (...). Man kunne have håbet, at det 21. århundrede havde forlenet det russiske militærapparat med en vis ansvarlighed. I dag må man sige, at det, desværre, er en naiv tankegang. Tilbageholdenheden ved Murens fald var en undtagelse.$^{14}$ Avisen konkluderede desuden (den 16. marts 2016), at "man må lade præsident Putin, at han har spillet sine kort koldt, kynisk og realpolitisk klogt (...). Stakkels Syrien".

Berlingske (den 3. oktober 2016) præsenterede en tilsvarende historisk fortolkning, da avisen beskyldte Rusland for at "[vende] tilbage til dets historiske tradition for at begå hæmningsløse overgreb på civile, sådan som det skete i Tjetjenien i 1990'erne, og som det skete under Den Kolde Krig, da kommunistiske herskere udryddede egne befolkningsgrupper", og tilføjede, at "Rusland begår i disse dage og uger dagligt krigsforbrydelser i Syrien". Som med maskirovka i BT, advarede Berlingske (den 15. februar 2016) om, at "det er på høje tid, at Vesten forstår, at man ikke kan fæste lid til, hvad Rusland siger, og udelukkende forholder sig til, hvad Rusland rent faktisk gør».

På denne måde blev Ukraine og $\mathrm{i}$ endnu højere grad Syrien også aspekter af Ruslands politiske udvikling i retning af det autoritære og illiberale. Det kom til at handle om politisk kultur og beslutningstagning, om manglende parlamentarisk og mediemæssig kontrol af den udøvende gren i Rusland, om forholdet mellem den russiske stat og det enkelte menneske og om stiafhængighed (Hedlund 2012). Jyllands-Posten (den 16. marts 2016) noterede med slet skjult kritik, at "der er sjældent langt fra ord til handling i Kreml. Da præsident Vladimir Putin i september [2015] pludseligt meddelte, at han ville sende russiske fly til Syrien, var de på vingerne over det borgerkrigshærgede land mindre end 24 timer senere, og da han [i marts 2016] meddelte, at 'hovedparten' af de russiske styrker trækkes ud af Syrien, havde de

\footnotetext{
${ }^{13}$ Se fx Trenin (2018).

${ }^{14}$ For en diskussion af Ruslands strategiske kultur og brugen af forsvaret som politisk instrument, se fx hhv. Covington (2016) og Poulsen \& Staun (2018).
} 
første fly allerede (...) kurs mod baserne i Rusland «. Russisk politik, som det fortolkes her, bliver til i konsultation med få fortrolige i inderkontoret på Kreml (Rubin 2016).

De mange andre dårlige sager har på samme vis affødt såvel konkrete som generelle kommentarer i lederspalterne. For eksempel blev anholdelsen af og dommen over Pussy Riot højlydt kritiseret af de danske aviser. BT (den 7. august 2012) vurderede, at den skarpe reaktion fra de russiske myndigheders side var en indikation på, at "præsident Putin for alvor begynder at stramme grebet om sine politiske modstandere«, og avisen så det som et tegn på, »hvor pinlig og presset den russiske præsident er». Samtidigt citerede BT den britiske avis The Guardian, som skrev, at »selv i sovjettiden, selv i Stalins tid, var retssalene mere ærlige«. Berlingske (den 18. august 2012) noterede på samme måde i en tvetydig overskrift, at Putin var "til grin", og med det mente man både, at Pussy Riot havde gjort grim med ham, og at han efterfølgende gjorde sig selv til grin ved at slå så voldsomt tilbage. Jyllands-Posten (den 18. august 2012) vurderede på baggrund af sagen mod Pussy Riot, at "Putin har grund til at være bekymret. Stadig flere aktive russere er utilfredse med hans såkaldte 'kontrollerede demokrati'" (Mandel 2005).

Den såkaldte homolov - loven "til beskyttelse af børn mod information, som propaganderer for en afvisning af traditionelle familieværdier« (Federalnyj zakon 2013) - har fået stor opmærksomhed i de danske medier og i den danske offentlighed generelt. Den fandt også vej til enkelte lederartikler. Politiken (den 8. marts 2013) opfordrede inden lovens endelige vedtagelse til »international handling ", dvs. en form for sanktioner, ved udsigten til "[statssanktioneret chikane] af homoseksuelle og andre seksuelle minoriteter i Rusland ". Avisen beskrev videre Rusland som "et af Europas mest homofobiske lande« og advarede om, at "homofobien ventes forstærket, hvis staten på den måde kriminaliserer homoseksualitet«. Også Berlingske (den 16. august 2013) fandt, at "det officielle Ruslands åbenlyse forfølgelse af en seksuel minoritet [er selvfølgelig] helt uacceptabel«, og avisen opfordrede til, at "presset [på Rusland] skal fastholdes«. Jyllands-Posten (den 17. august 2013) tog afstand fra »en stærkt usympatisk lov i Rusland mod såkaldt homoseksuel propaganda, der i praksis indebærer forbud mod at vise sin homoseksualitet offentligt «. Avisen opfordrede også til, at der "på det politiske niveau bør (...) protesteres ad de gængse kanaler, som den danske regering også aktuelt gør over for Rusland ", men den mindede samtidigt sine læsere om, at homoseksualitet er forbudt i »ca. 75 (...) lande i verden, hvilket ikke bør mindske kritikken af den russiske lovgivning, men dog sætter den i perspektiv«. Denne sidste kommentar rejser spørgsmålet, om vi vurderer forholdene i Rusland efter samme målestok som i andre lande, eller om vi måske er mere kritiske, og muligvis endog skal være mere kritiske, end vi ellers er. ${ }^{15}$

\footnotetext{
${ }^{15}$ Et argument for at vurdere Rusland efter en anden og højere standard end den brugt i forhold til lande uden for Europa kan fx være, at Rusland gør krav på en fælleseuropæisk identitet, hvis indhold (dvs. normer; Searle (1995)) bl.a. er beskrevet i Den Europæiske Menneskerettighedskon-
} 
Endelig var der drabet på Nemtsov tæt ved Kreml den 27. februar 2015 (Mommen 2016 og Lipman 2016). Politiken (den 2. marts 2015) noterede, med en indirekte reference til den politiske udvikling beskrevet tidligere, at "det er livsfarligt at kritisere præsident Vladimir Putin og hans politik", og avisen spurgte sig selv, "hvem bliver næste offer? Ingen kan vide sig sikker i et land, hvor politiske mord forbliver uopklarede«. Jyllands-Posten (den 3. marts 2015) spurgte samtidigt sig selv, "hvad siger likvideringen om Putins Rusland?», og avisen konstaterede, at "det er uomtvisteligt, at Putin bærer et ansvar, uanset hvem der trykkede på aftrækkeren. Putin har med sin stempling af Nemtsov og hans allierede som landsforrædere og femte kolonne skabt et klima, hvor voldsparate typer fandt, at de gjorde Kreml en tjeneste ved at myrde Nemtsov. Putin inviterede Nemtsov til skafottet«. Berlingske (den 28. februar 2015) konkluderede, at "hvis man har sit liv kært, gør man bedst i at lade være med at kritisere Putinstyret", inden avisen opsummerede både den politiske udvikling og status i Rusland med ordene:

\begin{abstract}
Når man derfor taler om Putins store popularitet i den russiske befolkning, må man forstå, at det bygger på gisninger. For det går enhver, der udfordrer Putin, ilde. Den politiske kamp er for længst holdt op med at foregå ved valgene; den foregår mellem valgene, hvor dygtige modstandere bliver fjernet fra arenaen. Retfærdigvis skal det siges, at Boris Nemtsov - så dygtig, karismatisk, smuk og slagfærdig han end var, næppe havde haft en chance mod Putin i et frit Rusland. Dertil var han alt for liberal i vestlig forstand til et land, der stadig er præget af halvfjerds års sovjetkommunisme.
\end{abstract}

\title{
Perspektivering
}

Meningsmålinger viser, at danskerne er blandt de mest Ruslandkritiske i EU. Eurobarometer fandt i 2017, at $83 \%$ af danskerne havde et "negativt" syn på Rusland. Denne del var fordelt med $50 \%$ på "noget negativt" og $33 \%$ på "meget negativt" (Europa-Kommissionen 2017: QC5.6). Til sammenligning var tallene hhv. 85 \% i Nederlandene, $81 \%$ i Sverige og $72 \%$ i Finland. Kun $11 \%$ af danskerne svarede, at de havde et "positivt" syn på Rusland - de tilsvarende tal for Nederlandene, Sverige og Finland var hhv. $11 \%$, $15 \%$ og $24 \%$ (Europa-Kommissionen 2017: QC5.6).

Opfattelsen af Rusland i den danske offentlighed er naturligvis også formet af dækningen af Rusland i de danske medier, herunder i lederartiklerne. Den overordnede tone i lederne er negativ, og kritikken er skarpere end i 2000 'erne. Jeg startede med at præsentere to aktuelle sager - det danske forsvarsforlig og debatten om Nord Stream 2 - og begge illustrerer en udvikling, hvor Rusland åbent bliver italesat som en udfordring for eller sågar en trussel mod Danmark eller nære allierede. Udviklingen synes at tage afsæt i indre forhold i Rusland, nærmere betegnet den stigende politiske kontrol og undertrykkelse af personlige friheder, og disse forhold har ifølge de danske lederskribenter bragt Rusland længere væk fra Vesten. I tilgift

vention, som Rusland aktivt har tilvalgt. Denne konvention forpligter Rusland ud over FN's Menneskerettighedskonvention. 
har vi så efterfølgende annekteringen af Krim og Ruslands militære engagementer i Østukraine og Syrien, som betragtes som angreb på ellers stadfæstede europæiske normer. Der er stor fokus på Putin, som beskrives som det helt centrale omdrejningspunkt i russisk politik, og hvis rolle det er at fastholde styret og de særinteresser, som styret repræsenterer, med de nødvendige midler. Aviserne tegner et billede af en kynisk præsident, som Vesten ikke kan stole på, hvilket betyder, at Vesten heller ikke kan stole på Rusland.

Jeg talte tidligere om et paradigmeskifte i opfattelsen af Rusland i Danmark. Det har i givet fald været en kontinuerlig proces, som er begyndt med russisk indenrigspolitik og i stigende grad er blevet næret af udenrigspolitiske forhold. Det er svært at identificere en enkelt begivenhed, men invasionen og annekteringen af Krim og det efterfølgende udbrud af krig i Østukraine har mere end andet påvirket de danske lederskribenters syn på Rusland. 2014 er på den måde skelsåret. Lederskribenternes brug af Hitler-analogien har lagt spor for den senere og fremtidige fortolkning af Putin og af det Rusland, som han nu leder i sin fjerde præsidentperiode. Forholdene ved invasionen og annekteringen af Krim og udbruddet af krig i Østukraine bekræftede dem blot i eksistensen af en russisk offentlighed, som enten er uforandret siden sovjettiden eller kuet af magthaverne eller blot politisk apatisk. Uanset baggrunden ser de et ensrettet Rusland uden kritisk samtale om Ruslands politik og egen udvikling.

Er der lyspunkter? De er i så fald vanskelige at få øje på. Der er kommentarer som i Berlingske (den 28. februar 2015), som argumenterer for, at undertrykkelsen er blevet så omfattende, at vi har svært ved at fornemme, hvad det russiske samfund egentligt indeholder. Jyllands-Posten (den 19. marts 2018) hæftede sig som nævnt ved, at mere end hver femte vælger valgte $i k k e$ at sætte kryds ved Putin ved præsidentvalget i mart 2018, og avisen ser i dette mulige problemer for Putin i form af et protestpotentiale og en anden kurs for Rusland. Men den generelle fortolkning synes at være, at Rusland mere eller mindre er låst fast i sin nuværende tilstand, og at Vesten skal indstille sig på det.

Ganske bemærkelsesværdigt har den behandlede periode også set fremkomsten af en debat om debatten. Denne debat er i høj grad sat i gang på baggrund af lederartiklerne. Der er ganske få referencer til denne debat i det indsamlede materiale. Berlingskes kommentar om, at "vi skal passe på med at dæmonisere Rusland, har omkvædet lydt" (den 31. august 2014) er sandsynligvis en sådan reference. Det er også en afvisning af kritikken af, at den danske offentlighed, herunder aviserne, er for ensidigt negative i deres dækning af Rusland. Der ligger i dette et interessant emne for forskere, mediefolk og politikere at undersøge og reflektere over, som der også gør i det bredere spørgsmål om, hvorledes vi »bedst håndterer Rusland«. Konklusionen, som den generelt er præsenteret i de danske lederartikler i årene 2010-2018, er, at Vesten bør være ganske fast $\mathrm{i}$ sin håndtering af Rusland, som bliver beskrevet som et land, som i stadig stigende grad udvikler sig i autoritær og illiberal retning, og hvis udenrigspolitik er aggressiv og grænseoverskridende. 


\section{Referencer}

Barlag, Rasmus (2016) »Rapport: Medierne taler en ny kold krig frem». Fournalisten (den 28. juni).

Bennetts, Mark (2018) "Don't Blame Journalists for Bad News About Russia». The Moscow Times (den 3. juli). Billeaudeaux, Andre, David Domke, John S. Hutcheson \& Philip Garland (2003) "Newspaper Editorials Follow Lead of Bush Administration«. Newspaper Research fournal 24 (1): 166-184.

Black, Joseph (2015) The Russian Presidency of Dmitry Medvedev, 2008-2012. London: Routledge

Checkel, Jeffrey (2001) "Why Comply? Social Learning and European Identity Change». International Organization 55 (3): 553-588.

Collignon, Pierre (2018) Tilbage til virkeligheden - kampen mod fake news, løgne og manipulationer. København: Gyldendal.

Covington, Stephen (2016) The Culture of Strategic Thought Behind Russia's Modern Approaches to Warfare. Cambridge, MA: Belfer Center for Science and International Affairs.

Dahl, Ann-Sofie (2018) (red.) Strategic Challenges in the Baltic Sea Region. Washington, DC: Georgetown University Press.

Donno, Daniela (2013) Defending Democratic Norms. Oxford: Oxford University Press.

Drezner, Daniel (2009) The Sanctions Paradox. Cambridge: Cambridge University Press.

Det europæiske Råd (u.d.) EU Restrictive Measures in Response to the Crisis in Ukraine. Tilgængelig på http:// www.consilium.europa.eu/en/policies/sanctions/ukraine-crisis/.

EU-Kommissionen (2017) Special Eurobarometer 467. Tilgængelig på http://data.europa.eu/euodp/en/data/ dataset/S2179_88_1_467_ENG.

EU-Kommissionen (2018) Russia - Trade Statistics. Tilgængelig på http://trade.ec.europa.eu/doclib/docs/2006/ september/tradoc_113440.pdf.

Federalnij zakon (2013) O vnesenii izmenenii v statju 5 Federalnogo zakona 'O zasjtite detei ot informatsii, pritjinjajusjtjej vred ikh zdorovju $i$ razvitiju' $i$ otdelnie zakonodatelnye akty Rossiiskoi Federatsii $v$ tseljakh zasjtiity detei ot informatsii, propagandirujusjei otritsanie traditsionnykh semeinykh tsennostei (den 29. juni).

Fish, Steven (2017) "What is Putinism?« fournal of Democracy 28 (4): 61-75.

Forsvarets Efterretningstjeneste (2017) Efterretningsmcessig risikovurdering 2017.

Forsvarsministeriet (2018) Aftale på forsvarsområdet 2018-2023. Tilgængelig på http://www.fmn.dk/temaer/ forsvarsforlig/Documents/Forsvarsforlig-2018-2023.pdf. Læst den 27. februar 2018.

Freedom House (2018) Freedom in the World 2018 - Russia Profile. Tilgængelig på https://freedomhouse.org/ report/freedom-world/2018/russia. Læst den 26. juni 2018.

Freeman, Colin (2014) »Russian Troops Poised to »Run« into Moldova, NATO Commander Warns». The Telegraph (den 23. marts).

Gelman, Vladimir (2015) Authoritarian Russia. Pittsburgh, PA: University of Pittsburgh Press.

Goldthau, Andreas (2016) Assessing Nord Stream 2: Regulation, geopolitics E energy security in the EU, central Eastern Europe $\&$ the UK. London: King's College.

Haagerup, Ulrik (2015) Constructive News. New York, NY: InnoVatio.

Hansen, Flemming Splidsboel (2010) "Danske billeder i 2000'erne«. Nordisk Østforum 24 (2): 167-183.

Hansen, Flemming Splidsboel (2016) "Russia's Relations with the West: Ontological Security through Conflict". Contemporary Politics 22 (3): 1-17.

Hansen, Flemming Splidsboel (2017) Russian Hybrid Warfare: A Study of Disinformation. København: DIIS.

Hansen, Flemming Splidsboel (2018) "Denmark - United in Opposition". I The Kremlin's Trojan Horses 3. Washington, DC: Atlantic Council.

Harcup, Tony \& Deirdre O’Neill (2017) »What is News?« fournalism Studies 18 (12): 1470-1488.

Hedlund, Stefan (2012) Russian Path Dependence. London: Routledge.

Heuer, Richards (1999) Psychology of Intelligence Analysis. Langley, VA: Central Intelligence Agency.

Inozemtsev, Vladislav (2017) »Putin's Russia: A Moderate Fascist State». The American Interest 12 (4).

Ioffe, Julia (2018) "What Putin Really Wants«. The Atlantic (januar/februar).

Izadi, Foad \& Hakimeh Saghaye-Biria (2007) "A Discourse Analysis of Elite American Newspaper Editorials". fournal of Communication Inquiry 31 (2): 140-165.

Javelin, Debra \& Sarah Lindemann-Komarova (2010) "A Balanced Assessment of Russian Civil Society«. fournal of International Affairs 63 (2): 171-188.

Gessen, Masha (2017) The Future is History: How Totalitarianism Reclaimed Russia. New York, NY: Riverhead Books. 
Kantar Gallup (2018) Leesertal. Tilgængelig på https://ns-gallup.dk/sites/default/files/2018-09/Index\%20 Danmark\%20Gallup\%20L\%C3\%A6sertal\%201H\%202018.pdf. Læst den 15. oktober 2018.

Kabel, Lars (2016) Danske mediers deekning af Rusland. Aarhus: Nordisk Journalistcenter.

Kolesnikov, Andrej (2017) Resjim negativnogo konsensusa. Moskva: Carnegie.

Kornprobst, Markus (2007) "Comparing Apples and Oranges? Leading and Misleading Uses of Historical Analogies". Millenium 36 (1): 29-49.

Krarup, Marie (2018) "Avisernes Ruslandsdækning«, opslag på Facebook (den 18. februar).

Liik, Kadri (2017) "What does Russia want« European Council on Foreign Relations (den 26. maj).

Lipman, Maria (2016) "At the Turning Point to Repression«. Russian Politics E Law 54 (4): 341-350.

Mandel, David (2005) "Managed Democracy: Capital and State in Russia». Debatte 13 (2): 117-136.

Mommen, Andre (2016) »Boris Nemtsov, 1959-2015. The Rise and Fall of a Provincial Democrat". Demokratizatsiya 24 (1): 5-28.

Muñoz-Torres, Juan Ramón (2012) "Truth and Objectivity in Journalism». Fournalism Studies 13 (4): 566-582.

Nordenson, Magdalena (2008) Opinionsjournalistik. Lund: Studentlitteratur.

Osmolovska, Aliona (2018) "Why the Seven Arguments to Justify Nord Stream II are Just Plain Wrong». Atlantic Council (den 30. april).

Pomerantsev, Peter (2017) Nothing is True and Everything is Possible. London: Faber \& Faber.

Poulsen, Niels Bo \& Jørgen Staun (2018) (red.) Kreml i krig. København: DJØF.

Retsinformation (2017) Lov om cendring af lov om kontinentalsoklen. Lov nr. 1401 (den 5. december).

Rose, Flemming (2018) »Hvilket europæisk land har siden 1998 haft størst økonomisk vækst?« Berlingske (den 15. oktober).

Ross, Angus \& Andrew Savchenko (2018) "The Obvious Question: What Does Russia Want?» The National Interest (den 11. april).

Rubin, Mikhail (2016)»Novoe "politbjuro« Putina: S kem teper sovjetuetsja prezident«. Dosjd (den 7. november); Tilgængelig på https://tvrain.ru/articles/polit-420486. Læst den 7. juli 2018.

Ryan, Michael (2004) "Framing The War Against Terrorism». The International fournal for Communication Studies 66 (5): 363-382.

Saari, Sinikukka (2009) Promoting Democracy and Human Rights in Russia. London: Routledge.

Sapper, Manfred \& Volker Weichsel (2015) (red.) Særnummer af Osteuropa 3: 1-208.

Searle, John (1995) The Construction of Social Reality. London: Allen Lane.

Shevtsova, Lilia (2014)»The Russia Factor«. Fournal of Democracy 25 (3): 74-82.

Shevtsova, Lilia (2015) "Forward to the Past in Russia". Fournal of Democracy 26 (2): 22-36.

Trenin, Dmitrij (2018) What is Russia Up To in the Middle East? Cambridge: Polity Press.

Tumakova, Irina (2018) „Oni tam byli«. Novaja Gazeta (den 24. juni). Tilgængelig på https://www.novayagazeta. ru/articles/2018/06/24/76916-oni-tam-byli. Læst den 26. juni 2018.

Uribe, Rodrigo \& Barrie Gunter (2004) »Research Notes: The Tabloidization of British Tabloids». European Fournal of Communication 19 (3): 387-402.

van Dijk, Teun A. (1998) "Opinions and Ideologies in the Press« i Allan Bell og Peter Garrett (red.) Approaches to Media Discourse. London: Blackwell: 21-63.

Wood, Elisabeth, William Pomeranz, Wayne Merry \& Maxim Trudolyubov (2016) Roots of Russia's War in Ukraine. Washington, DC: Woodrow Wilson Press Center. 